PRAGATI: Journal of Indian Economy Volume 4, Issue 1, January-June 2017, pp. 93-108 doi:10.17492/pragati.v4i01.9548

\title{
Self Help Group: A Strategy to Rural Development of Puri District in Odisha, India
}

\author{
Kailash Chandra Mishra*
}

\begin{abstract}
On the basis of a micro level study for Puri district in Odisha, this paper finds that the Self Help Groups (SHGs) have played a positive and significant role in generation of employment and income of its members engaged in different economic activities such as commercial farming, pisciculture, food processing, trade \& commerce, household industry and agriculture. The members are found to have a change in the quality of their lives. Promotion of SHGs therefore, not only helps foster rural development but also go a long way in attaining inclusive growth in India.
\end{abstract}

Keywords: Self Help Groups; Microfinance; Rural development; Quality of life; Employment; Income; Puri district.

\subsection{Introduction}

Rural development is the sine qua non for overall development of an economy like India that has a large population that lives in villages. More than 70 per cent of people in India live in rural areas and depend mostly on agriculture for their livelihood. Rural Development can be achieved only with the upliftment of the rural folk consisting of poor farmers, agricultural labourers and self-employed artisans (Mishra \& Mishra, 2008). Since agriculture is overcrowded and this sector has little hope of absorbing burgeoning population, they are to be engaged either in industrial activity or in other commercial activities which warrant financial investment. Finance being the lifeblood of any commercial venture, availability of adequate funds at reasonable terms is a must to ensure rapid rural economic development (Lenka \& Mishra 2008). It is now realised that microfinance plays a significant role in financing the target group members those who are living below poverty line (Yunus, 2004; Guha \& Gupta, 2005; Copestake, 2007; Tripathy \& Jain 2007).

*Assistant Professor of Economics, M. P. C. Autonomous College, Baripada, Odisha, India. (Email id: kailash_mishra2000@rediffmail.com) 
Further, women population which constitute almost 50 per cent of the rural population are either unemployed or underemployed. Understanding the gravity of the unemployment situation and low income, the Government of India has launched the Swarna Jayanti Gram Swarozgar Yojana (SGSY) in 1999. The objective of SGSY is that it will help formation of Self- Help Groups in the formative stage, nurture them and at a later stage it will generate income and employment which will lead to rural development in India. Unless and until all the needy women population is actively engaged in the Self-Help Group formation, rural development will not be possible. Hence, the present study emphasises on Self-Help Groups and examines the role of SHGs in rural development.

\subsection{Review of Literature}

This section reviews the existing literature on microfinance and the strategies undertaken in different regions for its effective execution. Yunus (2004) has found that Micro-credit programmes in Bangladesh have grown, providing a wide range of services to meet economic and extra economic needs of the citizens. The micro-credit effort in Bangladesh through Grameen Bank shows that micro-credit is effective in helping the poor people to use their own efforts and creativity to meet their basic needs in a sustainable manner. Satish (2005) cautions about the type of micro-finance through SHGs pointing out that the growth of micro-fiancé has to necessarily be accompanied with the overall growth in mainstream rural finance. He has also observed that if empowerment of poor, in general and of poor women, in particular, is being attempted through micro-finance at a time when all aspects of social banking in India are being jettisoned, it is unlikely that the goals of such an empowerment would be achieved and sustained in an enduring way.

Copestake (2007) has conducted an action research programme to study the performance management systems of a global sample of explicitly poverty oriented Micro Finance Institutions (MFIs). He has found that many MFIs do have strong social as well as financial performance preferences, significant room for manoeuvre in managing the poor, and that there is scope for them to do so better. Improved goal setting and strategic planning, routine monitoring of the poverty status of clients and exclients, a capacity for follow up research into the reasons behind observed changes and periodic reviews of these activities are the strength in the hands of these MFIs which help them to accelerate the pace of innovation and growth in a more poverty and gender aware manner. This study, in-spite of its significant findings, has not been able to satisfactorily answer the issues of (i) human capital deficiencies of the beneficiary 
micro-finance clients and (ii) the role of hostile physical and market environment where the micro-enterprises operate.

Shylendra (2008) observes that the economic impact of the SHGs has been more protective rather than promotional in nature. He further explains that this process is attributed to the exclusion of the very poor and to the general constraints faced by the poor in making use of loan for productive investments. This study has not provided light on the role of SHGs in social and economic empowerment in Indian society which can inspire the client beneficiaries to take up sustainable and diverse economic occupations under the micro-finance programmes so as to experience an appreciable enhancement in their income and asset. Lenka and Mishra (2008) made a micro study in Satyabadi Block of Puri District in Odisha and observed that Micro credit is a powerful instrument of poverty alleviation. It has not only increased the saving habit but also helped reducing intensity of poverty. It is also found that through an increase in income and employment, it has helped reducing the intensity of poverty but not has been able to alleviate poverty.

Mishra (2015) made a study and observed that finance is a major problem and disbursed amount is much less than the proposed amount. Further, the amount of outstanding loan among the SHG beneficiaries is found due to several problems like, Marketing, Finance, infrastructure, facilitator's support. Thereby SHGs are not able to be self-sustainable in rural India.

\subsection{Objectives and Hypotheses}

The major objectives of the present study are as follows:

- To assess the impact of SHGs on employment and income of the stake holders.

- To study the impact of SHGs on quality of life of its members.

- To suggest suitable policy options for successful working of the SHGs.

The following are the hypotheses of the study:

$\mathrm{H}_{1}$ : SHG participation has a positive impact on employment and income of the members. $\mathrm{H}_{2}$ : SHG participation has a positive impact on quality of life of its members.

\subsection{Data and Methodology}

The field study has been restricted to Puri district of Odisha, India. The sample of beneficiary respondents, in the study, has been drawn by employing multistage sampling technique. The respondents include leaders and members of SHGs. The following procedures have been applied while selecting the sample. All the Eleven Community Development Blocks (CDBs) of the district are chosen. From each CDB, 
four Gram Panchayats are selected randomly. From each selected Gram Panchayat, six SHGs are selected which are formed and financed in 2010-11. Response from one leader and one member of each selected SHG is collected through the requisite schedules. Thus a total of 528 beneficiary respondents from 264 SHGs are covered in this study. Moreover information from four non-SHG members in each sample Panchayat is elicited for comparative study. The primary data have been collected from two sets of respondents: one set of respondents is the beneficiaries (Members and Leaders) of SHGs and the other set of respondents is non-members of SHGs.

The study period spreads from April 2009 to March 2016. The pre-SHG period data relates to information in respect of the respondents from April, 2009 to March, 2010 and Post-SHG Period includes information from April, 2015to March 2016.

Simple statistical tools like percentages, ratios, growth rate, average and standard deviation are used for comparative analysis of the data. The relationship between different variables has been examined through cross tabulation of the data. Further, statistical inferences are drawn through the use of paired t- test to check whether the cross-tabulated variables are significantly associated. To know the impact of SHG participation and credit on income, OLS (Ordinary Least square) estimation is used.

\subsection{Profile of the study area}

The economic profile of the district reflects certain peculiarities that need attention. Puri is located in the eastern part of Odisha. Though in area it is one of the smallest districts of the state, it possesses a varied physiography. The historical background of the district along with geographical diversities contains the seeds of underdevelopment. The district is found to be an economically poor district with very low income and low per capita income compared to other districts of the state. The average density of population in the district is more than that of the state average. Eighty six per cent of the people in Puri district are living in rural areas and it indicates their poor economic condition.

Puri is agriculturally dominated but the land holding pattern is very much uneven. It is found that the average size of holding in Puri district is less than that of the state average. Lack of irrigation acts as stumbling block on the path of agricultural development. On the other hand, there is dearth of industries. Though there is the existence of some scale and cottage industries in the district. These industries are traditional in nature. They are not equipped with advanced technology. Due to lack of mines and mineral ores, no heavy or large scale industries can be established till date.

An enquiry has been made in the present study to assess the marine resource of the district. From the study it is found that the district has vast marine resources and a 
long coast line. However, the rate of exploitation of the resources is found to be low due to non-adoption of advanced technology. Human resource development and infrastructure penetration in the district are not satisfactory. A major percentage of villages lack all weather connectivity. The railway route length is only 42.08 K.M. Number of motor vehicles per thousand population is 24 . The airport facility is found to be absent. The banking facility is very much urban centered. Thus the infrastructural facility available is seen to be poor and a large number of people are unable to access the available opportunity. So Self Help Groups are the need of the hour for widening the livelihood options among the rural people, particularly women.

\subsection{Data Analysis}

This section provides an analysis of the socio-economic profile of the sampled SHG members obtained through primary survey.

\subsection{Social group wise distribution of sample beneficiaries}

The objective of SHG- Bank Linkage Programme (SBLP) is to provide financial services to poor, deprived and weaker section of the population. Table 1 shows the social group wise distribution of sample respondents. Caste system in the state Odisha particularly in rural area is very strong. It is found that majority of the SHG respondents belong to socially and economically backward classes. Out of 528 respondents, 47.16 per cent belong to SEBC, 21.21 per cent belong to Scheduled Castes and 2.08 per cent belong to Scheduled Tribes. The respondents from General category constitute 29.55 per cent in the study area. It is a matter of great satisfaction that poor people, irrespective of their castes are coming together for self-help and mutual help by way of SHGs.

Table 1: Social Group Wise Distribution of Sample Respondents

\begin{tabular}{|c|c|c|}
\hline Social Category & No. of Sample Beneficiaries in Puri District & \% to Total \\
\hline SC & 112 & 21.21 \\
\hline ST & 11 & 2.08 \\
\hline SEBC & 249 & 47.16 \\
\hline General & 156 & 29.55 \\
\hline Total & N $=528$ & 100 \\
\hline
\end{tabular}

Source: Primary data 


\subsection{Head of the household}

In the Indian family and social set up the head of the household plays a key role in all household affairs. The head here is defined as the person who decides important matters of family like use of family resources, assets to be acquired, children's education and marriage of the children etc. Since SHG aims at empowering women to participate in the decision making process of the family, in the present study, we have attempted to bring out the extent of women participating in the family decision making acting as head of the family. Table 2 presents required data in this respect. In the table it is observed that the sample households selected for the study are basically male headed. Only 4.5 per cent of the total sample households are female headed. Hence SHGs are very much essential to develop the decision making power among the women population, thereby women have a say in the decision making process.

\section{Table 2: Types of Sample Households}

\begin{tabular}{|c|c|c|}
\hline Types of Household & No. of Households & \% to Total \\
\hline Male headed Household & 504 & 95.45 \\
\hline Female headed Household & 24 & 4.55 \\
\hline Total & 528 & 100 \\
\hline
\end{tabular}

Source: Primary data.

\subsection{Occupation wise Distribution of Sample Households}

Table 3 represents the classification of sample households on the basis of their occupation namely, cultivation, business, daily labour, service and self-employment. Out of 528 sample households, 21.02 per cent sample households are cultivators. It is disappointing to note that 40.72 per cent households eke out their livelihood as daily labourers. But 10.61 per cent sample households are found to earn their livelihood from service. 16.67 per cent sample households are engaged in business whereas a mere 9.09 percentage belongs to self-employed for their livelihood.

\subsection{Size of the Households}

It is seen that members of SHG who have large family size and have high number of dependants in the families, often face higher levels of financial hardships. Guha and Gupta (2005) found that most of the members showed interest in joining SHGs because of their financial hardships. Based on the number of members, the selected households are broadly classified into four categories which are given in Table 4. It is found that, around 60 per cent members had four to six family members and 24 per cent 
members had seven to nine members. Very few SHG members had family size of ten or more members.

Table 3: Occupation wise Distribution of Sample Households

\begin{tabular}{|c|c|c|}
\hline Occupation & Total No. of Households & \% to Total \\
\hline Business & 88 & 16.67 \\
\hline Cultivation & 111 & 21.02 \\
\hline Daily Labour & 215 & 40.72 \\
\hline Service & 56 & 10.61 \\
\hline Self-Employment & 48 & 9.09 \\
\hline Others & 10 & 1.89 \\
\hline Total & 528 & 100 \\
\hline
\end{tabular}

Source: Compiled from the data collected

Table 4: Distribution of the Households according to Family Size

\begin{tabular}{|c|c|c|}
\hline Size of the Family & No. of Households & \% to Total \\
\hline Upto 3 members & 72 & 13.6 \\
\hline $4-6$ & 318 & 60.2 \\
\hline $7-9$ & 127 & 24.1 \\
\hline 10 and above & 11 & 2.1 \\
\hline Total & 528 & 100 \\
\hline
\end{tabular}

Source: Compiled from the data collected

\subsection{Age of Members}

On the basis of age Groups i.e. 18-25, 26-35, 36-55 and above 55 years the distribution is framed. Table 5 shows the sample SHG members classified according to different age categories. It can be observed from the table that the largest proportion of the sample SHG members was in the age group 36-55years. A very small percentage of members belong to the age group above 55 in the sample SHGs. It appears that old people tend to leave SHGs. Some of the members revealed that these members left the SHGs as they could not work and save due to old age. Death of some members due to old age was also the reason for reduction of older members in some of the SHGs.

\subsection{Marital Status of the Sample Households}

Table 6 shows the marital status of the sample households in the district. It is found that 90.5 per cent beneficiaries are married while 6.8 per cent beneficiaries are 
unmarried and only 2.7 per cent beneficiaries are widow. Further, it is found that married persons are participating in SHGs more actively than any other beneficiaries.

Table 5: Distribution of SHG Members According to Age

\begin{tabular}{|c|c|c|}
\hline Age in Years & No. of beneficiaries & \% to Total \\
\hline $18-25$ & 61 & 11.6 \\
\hline $26-35$ & 177 & 33.5 \\
\hline $36-55$ & 271 & 51.3 \\
\hline Above 55 & 19 & 3.6 \\
\hline Total & 528 & 100 \\
\hline
\end{tabular}

Source: Primary data

Table 6: Marital Status of the Sample Households

\begin{tabular}{|c|c|c|}
\hline Marital Status & No. of Household & \% to Total \\
\hline Unmarried & 36 & 6.8 \\
\hline Married & 478 & 90.5 \\
\hline Widow & 14 & 2.7 \\
\hline Total & 528 & 100 \\
\hline
\end{tabular}

Source: Primary data

\subsection{Economic Status of the Sample Households}

Table 7 reflects the distribution of the sample households on the basis of economic status. In the present research the economic status is discussed under two heads, i.e. BPL and the non-BPL or APL. It is observed that out of 528 respondents, 489 $(92.61 \%)$ are from below the poverty line (BPL) and only 7.39 per cent are from nonBPL category. This clearly indicates that the respondents are mostly from the BPL category. In order to bring the poorest of the poor above poverty line, Micro finance initiatives through self-help groups must be extended on a large scale.

Table 7: Distribution of Sample Respondents by Economic Status

\begin{tabular}{|c|c|c|}
\hline Category & No. of Sample respondents of Puri District & \% to Total \\
\hline BPL & 489 & 92.61 \\
\hline Non- BPL & 39 & 7.39 \\
\hline Total & 528 & 100 \\
\hline
\end{tabular}

Source: Primary data

Notes: BPL refers to people below the government specified poverty line; Poverty line income was kept at Rs. 65.75 per day which was the benchmarked poverty line followed by Government of India. 


\subsection{Size of Landholding of Sample Households}

Information is elicited from sample households on the size of the land they operate. The present research classifies the total sample in five categories in relation to status of land holding which is given below. As shown in Table-8, 17.61 per cent of the respondents are landless and 21.21 per cent possessed land upto 1 acre only. While 49.62 per cent of the respondents own between 1 and 3 acres of landed property, 8.33 per cent of respondents own between 3 and 5 acres and only 3.22 per cent of respondents possess more than 5 acres of landed property. This indicates that almost all of the SHG members are either landless or small or marginal farmers.

Table 8: Distribution of Respondents According to their Land Holding Size

\begin{tabular}{|c|c|c|}
\hline Land holding size (in Acres) & No. of Sample respondents & \% to Total \\
\hline$<1$ & 112 & 21.21 \\
\hline $1-3$ & 262 & 49.62 \\
\hline $3-5$ & 44 & 8.33 \\
\hline$>5$ & 17 & 3.22 \\
\hline Landless & 93 & 17.61 \\
\hline Total & 528 & 100 \\
\hline Source: Primary data & &
\end{tabular}

\subsection{Educational Status of the Beneficiaries of the Sample Households}

The availability and usage of any system depends on the level of understanding by the people for whom the system is meant for. Further the members can take advantages of any system if they are well educated to understand and take advantages accordingly. But the incidence of illiteracy in remote rural areas is a matter of serious concern. Further, high incidence of illiteracy among the SHG members caused higher dependency on leaders, poor record keeping and inability to meet the demand for loans (Shylendra , 2004). Illiteracy is a big obstacle in growth of SHGs. The distribution of respondents by their educational status is given in Table 9. As far as literacy level of the respondents in study is concerned, 57.01 per cent of the respondents are literates, while 42.99 per cent are illiterate. Out of 528 respondents, 34.66 per cent have studied up to primary level, 14.77 per cent up to secondary level and 7.2 per cent till higher secondary standard. Only 0.38 per cent of the respondents are found to possess a graduate degree.

\subsection{Income status of sample Households}

The economic background of the 528 sample respondents has been described in Table 10. Out of the total respondents, while 66.86 per cent are earning per 
day Income up to Rs.50/- , 28.03 per cent found to be earning from Rs.51 to Rs.100 a day (Table- 10). The income distribution in the district also indicates inequitable distribution pattern. While none of the respondents is found to be in the income class above Rs.150. It may, therefore, be construed that most of the sample respondents belong to BPL (Below Poverty Line) category.

Table 9: Education wise Distribution of Sample Beneficiaries

\begin{tabular}{|c|c|c|}
\hline Educational Qualification & No. of Sample respondents & \% to Total \\
\hline Illiterate & 227 & 42.99 \\
\hline Primary & 183 & 34.66 \\
\hline Secondary & 78 & 14.77 \\
\hline Higher Secondary & 38 & 7.20 \\
\hline Graduation or above & 02 & 0.38 \\
\hline Total & 528 & 100 \\
\hline
\end{tabular}

Source: Primary data

Table 10: Distribution of Sample Respondents by Daily Income Per-Capita

\begin{tabular}{|c|c|c|}
\hline $\begin{array}{c}\text { Income Class } \\
\text { (Per Capita per Day in Rs.) }\end{array}$ & No.of Sample respondents & \% to Total \\
\hline $0-50$ & 353 & 66.86 \\
\hline $51-100$ & 148 & 28.03 \\
\hline $101-150$ & 27 & 5.11 \\
\hline Above 150 & 0 & 0.00 \\
\hline Total & 528 & 100 \\
\hline
\end{tabular}

Source: Primary data

\subsection{Savings Status of Sample Households}

Out of the total sample respondents in Puri district,15.53 per cent of respondents have saved up to Rs. 30 a month (Table 11) while 22.35 per cent of respondents save from Rs.31 to Rs.60, 57.58 per cent save between Rs.61 and Rs.100 and only 4.54 per cent save above Rs.100 per month.

From the analysis of socio-economic profile of the sample respondents, it is observed that more than half of the respondents belong to socially disadvantaged groups like SEBC, SC and ST. Most of the respondents are landless labourers, marginal farmers and small farmers with an income below poverty line. The respondents are less educated and lack scientific temper. Among the literate respondents, most of them have only 
primary education which is not sufficient to be aware about the SHGs functioning and record keeping. Thus, it may be pointed out that the district needs special attention for improvement of education, employment and income so as to foster rural development.

Table 11: Distribution of Sample Respondents by Monthly Savings Contributed

\begin{tabular}{|c|c|c|}
\hline Savings Per Capita per month (Rs.) & No. of Sample respondents & \% to Total \\
\hline$\leq 30$ & 82 & 15.53 \\
\hline $31-60$ & 118 & 22.35 \\
\hline $61-100$ & 304 & 57.58 \\
\hline$>100$ & 24 & 4.54 \\
\hline Total & 528 & 100 \\
\hline
\end{tabular}

Source: Primary data

\subsection{Major Findings of the Study}

In the study area, the sample beneficiaries are engaged in different income generating activities. For the sake of simplicity and convenience, all the economic activities have been grouped into eight sub heads.

- Agriculture includes cultivation of paddy, pulses and turmeric.

- Commercial farming includes production of sugarcane, betel leaves, mushroom, vegetables and fruits such as coconut, cashew, sapota, jackfruit, pineapple, guava, lemon and orange.

- Food processing includes rice making, arisha \& kakara pitha preparation, juice, sauce, jelly, jam, pickle preparation, buddy, papad and mixture making, chips and muduki making, biscuit and mudhi making, tamarind processing.

- Pisciculture includes fresh water fishery, marine fishery, prawn culture, dry fish.

- Livestock includes dairy, goat and sheep rearing, poultry, piggery, bee keeping.

- Household industry includes making of agarbatti, bag, balita , basket, broom, candle, chandua \& cloth appliqué, coir rope, furniture, handicraft, phenyl preparation, pottery and terracotta, toy and appliqués, ricelflour huller.

- Trade and commerce includes cloth shop, imitation jewellery shop, fertiliser \& pesticide storage and selling, flower vending, groccery business, sweet shop and stationary shop.

- Others include cycle repairing, net weaving, Brick kiln, Laundry, Catering Services, Mid-Day meal cooking, Tent house, Sea shell and Shipa. 
No doubt that any financial assistance, if utilised properly, generates gainful employment opportunities in the rural economy. It was found that the sample respondents also got gainful employment opportunities. Thus employment situation in the pre and post SHG periods for the sample beneficiaries is discussed in this section.

The important findings that emerged from the present study are noted below.

\subsection{Employment}

- It is observed that in pre-SHG period, the average employment which was 163 person days increased to 235 person days in post-SHG period and registered a growth of 30.56 per cent. However, the growth of employment across different economic activities is found to be different. In the case of Pisciculture, there is highest percentage (61.96) increase in employment contrast to lowest percentage (4.86) increase in the case of 'Trade and commerce'. Pisciculture is followed by food processing, household industry and commercial farming where growth of employment is more than the average growth. On the other hand, 'trade and commerce' preceded by 'livestock' and 'others' have growth of employment less than the average growth. In the case of 'agriculture' the growth of employment is 23.93 per cent. Though the growth of employment is less than the average growth yet, a large section of the population is engaged in agriculture. So agriculture still dominates the employment absorbing sector of the economy.

- By applying paired $t$-test it is found that there is significant difference in employment generation between pre and post SHG Periods. In other words, there is a significant Change in the generation of employment due to participation in SHG. The activity wise results of paired t-test reveal that except livestock, Trade\& Commerce, all other activities generated significant employment due to SHG participation. Activities like agriculture, Commercial Farming, Food Processing, Pisciculture and Household industry therefore are found to have greater potential to generate additional employment opportunities in the district.

\subsection{Income}

- The average income of the respondents increased from Rs 18,847.63 in the Pre-SHG period to Rs $29,941.76$ in the Post-SHG period registering a growth of 58.86 per cent.

- Activity wise growth of income reveals that in commercial farming, the generation of income is highest (i.e.100.36 per cent) whereas in livestock, the generation of income is found lowest (i.e 4.63 percent). 
- Application of paired t-test shows that there is significant difference in income generation between Pre \& Post SHG Periods. In other words, there is a significant Change in the generation of income due to participation in SHG. Activity wise results of t-tests reveal that all the activities except livestock are proved effective in generating income. The activities like agriculture, commercial farming, food processing, trade \& commerce, pisciculture and household industry have significant potential in generating income in the district of Puri.

\subsection{Productivity of employment}

- The SHG has a significant impact on income which is evident from the estimation. The regression co-efficient of SHG participation is 0.673 , which indicates that the income of the respondents has increased by 67.3 per cent due to SHG participation/member of SHG.

- It is interesting to note that the SHG beneficiaries productively make use of their increased income. 39.2 per cent of the respondents reinvested their income on activities in which they are engaged, 9.66 per cent of them revealed that a major part of the income generated was utilised for educating their children and 10.61 per cent of them spent it on health care. 24.81 per cent of the respondents told that income generated was spent for meeting the consumption expenditure and 15.72 per cent told that income generated was used for creation of new assets. In general, the field experiences reveal that the strategy of SHGs is productive enough and had a favourable effect on employment and income generation. It is also observed that there is a quality improving effect on the families of sample respondents because majority of the beneficiaries utilized the income generated either for investing or improving the educational and health requirements. These expenditures resulted in qualitative improvement of human resources or in short it leads to human development.

\subsection{Social impact of SHGs}

- The present study reveals that 58.52 per cent respondents have learnt the lessons of co-operation and positive thinking after joining SHGs. 28.22 per cent members have developed sense of responsible citizens, 30.11 per cent have positive response to social changes, 57.20 per cent have self-respect and self-confidence and 53.22 per cent have developed leadership qualities. So it is evident that Self Help Groups are instrumental in all round development of the under privileged and neglected sections of the society. 


\subsection{Problems of SHGs}

- The SHGs are facing a number of problems while undertaking income generating activities. It is observed that 26.14 per cent of the total sample respondents perceived marketing as the main problem whereas 53.22 per cent experienced problems pertaining to timely and adequate availability of finance. While 12.31 per cent of respondents perceive product and quality and 6.25 per cent perceive infrastructure as the main problem in the successful implementation of their self-employment ventures, only 2.08 ascribed facilitators' support as the problem area.

\subsection{Conclusion and Policy Recommendations}

On the basis of the above findings the following suggestions are made for successful working of the SHGs. A careful selection of key activities in a particular area based on local physical and human resources and market demand is vital for the successful operation of micro enterprises. The group should maintain proper accounts of their thrift collected and loans distributed amongst the members. There is a need to provide adequate and timely finance for effective functioning of SHGs. Other recommendations include adequate infrastructure, capacity building and skill upgradation, creation of adequate marketing facilities. There is also a need for effective supervision and monitoring of investment activities. Finally, a strong political will and inspection of the end use of the loan are also important factors that determine the effectiveness of SHG as a strategy for financial inclusion.

From the analysis it is construed that the Self Help Groups have emerged as a powerful instrument for rural development. Especially, the SHGs in Puri District have brought the disadvantaged and vulnerable groups into the realm of development through the provision of finance and other inputs. The beneficiaries of these groups have been able to generate additional income and employment by utilising the funds in various income generating activities. Unless these functionaries serve the rural poor with strong urge and devotion, the purpose of SHGs will be defeated. It is therefore imperative to take a holistic approach to bring about rural development which will not only foster socio-economic development but also go a long way in attaining inclusive growth in India.

\section{References}

Amin, S, Rai, A. \& Topa, G. (2003). Does microcredit reach the poor and vulnerable, Evidence from Northern Bangladesh. Journal of Development Economics, 70(21), 59-82. 
Copestake, J. (2007). Mainstream microfinance: Social performance management or mission drift? World Development, 35(10), 1721-1738.

Guha, S. \& Gupta G. (2005). Micro-credit for income generation: The role of Rosca. Economic and Political Weekly, 40(4), 1470-1473.

Lenka, J. \& Mishra, K.C. (2008). Microfinance: A strategy for alleviation of poverty. Orissa Economic Journal, 40(1\&2), 48-54.

Lokhande, M. A. (2008). Socio-economic impact of micro financing through self - help groups in Marathwada region. The Indian Journal of Commerce, 61(4), 151-164.

Meher, Shibalal. (2004). Impact of microfinance on poverty: A study of self-help groups in Orissa. Working Paper No.54, Nabakrushna Choudhury Centre for Development Studies, Bhubaneswar.

Mishra, K.C.(2015). Financial adequacy and problems of self help groups: A study of Puri district in Odish. Uttaranchal Business Review, 5(1), 1-12.

Mishra, K.C. \& Mishra, R.C. (2008). Rural development in India: Emerging challenges and task-ahead. Southern Economist, 47(8), 5-8.

Mosley, P. \& Hulme, D. (1998). Microenterprise finance: Is there a conflict between growth and poverty alleviation? World Development, 26(5), 783-790.

Nair, S. (2005). The transforming world of Indian microfinance. Economic and Political Weekly, 40(17), 1695-1698.

Pillai, B, Vijayachandran \& Harikumar, V. (2006). Self help groups in Kerala. Kurukshetra, 54(9), 30-32.

Ramakumar, R. \& Chavan, P. (2005). Micro-credit and rural poverty - An analysis of empirical evidence. Economic and Political Weekly, 37(10), 955-965.

Satish P. (2005). Mainstreaming of Indian microfinance. Economic and Political Weekly, 40(17), 1731-1739. 
108 | PRAGATI: Journal of Indian Economy, Volume 4, Issue 1, January-June 2017

Shylendra, H. (2004). The SHG-bank linkage programme: An assessment and future strategies. Journal of Rural Development, 23(4), 411 - 433.

Tripathy, K. \& Jain, Sudhir, K. (2007). Micro-finance and Self-employment initiatives under SGSY: A Review of intentions and realities. Productivity, 47(4), 387-393.

World Bank. (2006). World Bank in microfinance in South Asia: Toward financial inclusion for the poor. Washington DC: The World Bank.

Yunus, M. (2004). Grameen bank, micro credit and Millennium Development Goals. Economic and Political Weekly, 39(36), 4077-4080. 